\title{
Chemical composition and functional properties of pumpkin pomace-incorporated crackers
}

\author{
Veronika Kuchtová, Jolana Karovičová, \\ Zlatica Kohajdová, Lucia Minarovičová \\ Institute of Food Science and Nutrition, Faculty of Chemical and Food Technology, \\ Slovak University of Technology, Radlinského 9, 81237 Bratislava, Slovak Republic \\ veronika.kuchtova@stuba.sk
}

\begin{abstract}
Pumpkin pomace obtained from cultivar (Cucurbita moschata Duch) was analyzed for their chemical composition and functional properties. Pumpkin pomace powder contained more than 50 mass \% of total dietary fibre and showed high hydration properties such as water holding capacity $\left(5.70 \mathrm{~g}^{-1} \mathrm{~g}^{-1}\right)$ and swelling capacity $\left(10.26 \mathrm{~cm}^{3} \cdot \mathrm{g}^{-1}\right)$. The effect of pumpkin pomace incorporation to wheat dough by replacement of wheat flour with pumpkin pomace ( 5 or $7.5 \%$ ) on physical properties (volume, volume index, width, thickness, spread ratio) and sensory parameters (appearance, hardness, taste, odor, overall acceptability) of cracker were evaluated. The results indicated that the addition of higher amount ( $7.5 \%$ mass) of pumpkin pomace powder negatively affected the volume, volume index, spread ratio and reduced their overall acceptance. Pumpkin pomace is a good source of ash and dietary fibres and may be incorporated into baked goods as a functional ingredient.
\end{abstract}

Keywords: pumpkin, dietary fibre, crackers, chemical composition, functional properties

\section{Introduction}

The demand for fruit and vegetable products as sources of dietary fibre (DF) is currently increasing due to their high nutritional quality, total and soluble fiber contents, fermentation and water retention levels, higher antioxidant capacity and lower caloric content (Rodríguez et al., 2006). Pumpkins belonging to Cucurbita pepo L. (called also 'squash'), Cucurbita maxima Duch (called 'winter squash') and Cucurbita moschata Duch ex Poir species are mostly grown in Central Europe countries. Since pumpkin species and cultivars differ in nutritional and technological value of fruits, breeders and scientists seek genotypes with the highest suitability for human nutrition (Gajewski et al., 2008). Pumpkins can be found in many shapes, sizes and colours. Agriculture, food-processing, pharmaceutical as well as feed industry have all taken growing interest in pumpkin fruit and pumpkin-derived products in past few years because of the nutritional and health-protective value of the proteins and oil from the seeds as well as the polysaccharides from the fruit (Saelaw and Schleining, 2011). Pumpkin is consumed in a variety of ways such as fresh or cooked as well as being stored, frozen or canned (Kundu et al., 2014). Pumpkin is a good source of $\beta$-carotene, fibre, pectin, mineral salts, vitamins and other substances that are beneficial to health (Jun et al., 2006; Kundu et al., 2014). These facts lead to the processing of pumpkin into various food products. It has been used to supplement cereal flours in bakery products, soups, sauces, instant noodles, spice, or as a natural colouring agent in pasta and flour mixes (Saelaw and Schleining, 2011). The aim of this study was to investigate the suitability of pumpkin pomace for cracker products. The chemical composition and functional properties of pumpkin pomace were determined. The effect of incorporation of pumpkin pomace on cracker quality and sensory acceptance were also studied.

\section{Material and methods}

Raw materials: pumpkin (Cucurbita maxima Duch), fine wheat flour (FWF) and other ingredients for crackers preparation were purchased from a local market in Slovakia. The fresh pumpkins were cleaned, peeled, cleaned of seeds, sliced into pieces $1.5 \mathrm{~cm}$ thick, and then washed in cold tap water. The pumpkin pulp was dried at room temperature for 7 days, ground using a commercial grinder (Model 001, ETA, Hlinsko, Czech Republic) and sieves were used to obtain powder particle of the size of $150-750 \mu \mathrm{m}$. Pumpkin pomace (PP) was stored at laboratory temperature in sealed paper containers prior to further analyses.

\section{Chemical analysis}

Moisture and ash content were determined according to Sowbhagya et al. (2007). Lipids were determined gravimetrically by the Soxhlet extraction. Nitrogen content was estimated by Kjeldahl method and was converted to protein using a factor 6.25 (Ayadi et al., 2009). Total dietary fibre (TDF) content of the pumpkin pomace was determined using of the Megazyme International total DF assay kit (adopted from AACC method 32-07 and AOAC 
method 985.29) (Sun-Waterhouse et al., 2010). The measurement of $\mathrm{pH}$ samples was performed according to Kohajdová and Karovičová (2007). Pectin content was determined by the gravimetric method described by Kohajdová et al. (2012).

\section{Determination of functional properties}

Hydration properties: water retention capacity (WRC), water holding capacity (WHC) and swelling capacity (SW) were determined according to method described by Raghavendra et al. (2004). Oil absorption capacity (OAC) was determined according to the method of Noor and Komathi (2009). Foaming capacity (FC) and foaming stability (FS) were determined performing to the method of Siddiq et al. (2010).

\section{Preparation of crackers}

Crackers were prepared according to the method of by Han et al. (2010). This procedure involved mixing dry ingredients, except sugar and separately mixing liquid ingredients (water, oil) and sugar. Fine wheat flour was replaced by PP at varied amount as follows: 0, 5.0 and $7.5 \%$. Ingredients were mixed into cohesive dough, rolled into a consistent, thin sheet and cut with circular shape into pieces. The crackers were baked in a forced-air convection oven (Mora, New Euroline, 524) at $175^{\circ} \mathrm{C}$ for $4 \mathrm{~min}$. Baked samples were then cooled at ambient temperature, and stored in sealed bags at room temperature.

\section{Determination physical parameters of crackers}

Crackers were evaluated for their physical properties (volume, volume index, width, thickness, spread ratio) parameters were measured. The width, thickness were measured a calibrated ruler as described by Ayo et al. (2007). Spread ratio = Width/Thickness. Volume index of samples was measured by method described by Turabi et al. (2008). Cracker volume was determined using a method described by Bouaziz et al. (2010).

\section{Sensory evaluation of crackers}

Sensory evaluation of crackers was performed using a 9 -points hedonic scale method $(1=$ dislike extremely, 2 = dislike very much, 3 = dislike moderately, 4 = dislike slightly, $5=$ neither like nor dislike, $6=$ like slightly, 7 = like moderately, $8=$ like very much, and 9 = like extremely) by 9 trained assessors according to method described by Vasantharuba et al. (2012). Panelists were required to evaluate the odor, hardness, taste and texture of the crackers. Overall acceptability of crackers was assessed using $100 \mathrm{~mm}$ graphical non-structured abscissas with the description of extreme points (minimal or maximal intensity, from 0 to $100 \%$ ) (Kohajdová et al., 2011).

\section{Statistical analysis}

Statistical analysis: All analyses were carried out in triplicate and average values were calculated. The results were expressed as mean \pm standard deviation. One-way analysis of variance (ANOVA) and Fisher's least - significant difference ( $L S D)$ multiple range test were used to establish the significance of differences at the level of $\mathrm{p}=0.05$. Statgraphic Plus, Version 3.1 (Statistical Graphic Corporation, Princeton, USA), was used as the statistical software.

\section{Results and discussion}

\section{Chemical analysis}

Chemical composition of fine wheat flour and PP is presented in the Table 1. It shows that pumpkin pomace exhibited relatively high TDF content $(51.77 \%)$. Similar results were described by authors Nawirska and Kwasniewska (2005) in carrot pomace (54.2\%), but higher that those reported by de Escalada Pla et al. (2007) in different insoluble residues of pumpkins (78.4-79.6\%). Moreover, it was found that $\mathrm{PP}$ is a rich source of ash $(6.65 \%)$ and pectins $(8.15 \%)$. On the other hand, PP was found to have a low fat content $(1.15 \%)$. The possible cause of lower fat content in PP is the removal of the peel, which may contain more fat than the pulp (Noor and Komathi, 2009).

Tab. 1. Chemical analysis of FWF and PP.

\begin{tabular}{lcr}
\hline & FWF & \multicolumn{1}{c}{ PP } \\
\hline Moisture (\%) & $10.54 \pm 0.31$ & $8.89 \pm 0.01$ \\
Ash (\%) & $0.48 \pm 0.00$ & $6.65 \pm 0.09$ \\
Protein (\%) & $9.40 \pm 0.19$ & $12.35 \pm 0.36$ \\
Fat (\%) & $1.15 \pm 0.04$ & $1.63 \pm 0.06$ \\
Pectins (\%) & $*$ & $8.15 \pm 0.33$ \\
TDF (\%) & $2.19 \pm 0.05$ & $51.77 \pm 0.18$ \\
pH & $6.26 \pm 0.03$ & $6.04 \pm 0.01$ \\
\hline
\end{tabular}

"Not detected, FWF - fine wheat flour, PP - pumpkin pomace, TDF - total dietary fibre.

\section{Functional properties}

Functional properties are the intrinsic physicchemical characteristics which may affect the behavior of food systems during processing and storage (Saleaw and Schleining, 2010). Functional properties of FWF and PP are shown in Table 2. Pumpkin pomace was characterized by a relatively high WHC $5.70 \mathrm{~g} \cdot \mathrm{g}^{-1}$. Lower WHC was described by Noor and Komathi (2009) for unpeeled pumpkin pulp flour $\left(2.56 \mathrm{~g} \cdot \mathrm{g}^{-1}\right)$ and for peeled pumpkin pulp flour $\left(1.52 \mathrm{~g} \cdot \mathrm{g}^{-1}\right)$. Previously, it was stated that high WHC depends on the content soluble DF 
comprising some components in the plant tissue materials having the ability to hold water such as pectin, fructan and arabinoxylan, while the higher content of protein and fat are retarding hydration capacity of DF (Wachirasiri et al., 2009). Moreover, the WHC of the fiber is also affected by different particle sizes. Smaller particle size lowers the fibres capability of holding water and is perhaps due to the fact that the small particle size has higher fiber density, which reduces the WHC. Small particle sizes also facilitate the loss of soluble DF components (Muhamad et al., 2015). PP exhibited SW value $10.26 \mathrm{~cm}^{3} \cdot \mathrm{g}^{-1}$. These values are similar to those published by Kohajdová et al. (2012) for carrot pomace $\left(10.48 \mathrm{~cm}^{3} \cdot \mathrm{g}^{-1}\right)$. Higher $\mathrm{SW}$ values were reported for wheat $\left(7.1 \mathrm{~cm}^{3} \cdot \mathrm{g}^{-1}\right)$, apple $\left(3.4 \mathrm{~cm}^{3} \cdot \mathrm{g}^{-1}\right)$ and oat $\left(2.3 \mathrm{~cm}^{3} \cdot \mathrm{g}^{-1}\right)$ (Mora et al., 2013). OAC assesses the ability of DF to absorb fat. Ingredients with high OAC play an important role in stabilizing food systems with high fat content and can act as emulsifiers (Grigelmo-Miguel and Martin-Belloso, 1998). The OAC of PP was $2.63 \mathrm{~g} \cdot \mathrm{g}^{-1}$, which was higher than that of unpeeled $\left(1.36 \mathrm{~g} \cdot \mathrm{g}^{-1}\right)$, and peeled (1.07 g. $\left.\mathrm{g}^{-1}\right)$ pumpkin flour described by Noor and Komathi (2009).

According to Kaur and Singh (2005), more hydrophobic proteins show superior binding of lipids, implying that non-polar amino acid side chains bind the paraffin chains of fats. Based on this suggestion, it could be inferred that PP, which showed higher OAC, had more available non-polar side chains in its protein molecules than did FWF. It can be seen that PP exhibited low FC $\left(14.50 \mathrm{~cm}^{3} \cdot 100 \mathrm{~cm}^{-3}\right)$ and FS $\left(8.50 \mathrm{~cm}^{3} \cdot 100 \mathrm{~cm}^{-3}\right)$, although it was higher than in FWF (Table 2).

\section{Physical properties of pumpkin pomace-incorporat- ed cracker}

Physical properties of pumpkin pomace-incorporated crackers are shown in the Table 3. The volume has a great importance in determining the quality because it is generally influenced by the quality of the ingredients used in the formulation of crackers (Perez and Germani, 2007). Volume of PP-incorporated crackers decreased with the increased level of PP. This might have been due to the dilution of gluten protein after incorporation of fibre (Pomeranz et al., 1977). The decrease in volume index was also observed upon increasing the PP addition. Moreover, it was found that the addition of PP caused the decrease of width and increase of thickness in crackers, resulting in a reduction the spread ratio. Decrease of width and increase of thickness led to reduction of the spread

Tab. 2. Functional properties of PP and FWF.

\begin{tabular}{|c|c|c|}
\hline Functional parameters & FWF & $\mathbf{P P}$ \\
\hline Water holding capacity $\left(\mathrm{g} \cdot \mathrm{g}^{-1}\right)$ & $2.63 \pm 0.16$ & $5.70 \pm 0.09$ \\
\hline Water retention capacity $\left(\mathrm{g} \cdot \mathrm{g}^{-1}\right)$ & $1.82 \pm 0.02$ & $1.25 \pm 0.02$ \\
\hline Swelling capacity $\left(\mathrm{cm}^{3} \cdot \mathrm{g}^{-1}\right)$ & $2.40 \pm 0.00$ & $10.26 \pm 0.15$ \\
\hline Oil absorption capacity $\left(\mathrm{g} \cdot \mathrm{g}^{-1)}\right.$ & $0.05 \pm 0.05$ & $2.63 \pm 0.16$ \\
\hline Foaming capacity $\left(\mathrm{cm}^{3} .100 \mathrm{~cm}^{-3}\right)$ & $1.5 \pm 0.01$ & $14.50 \pm 0.01$ \\
\hline Foaming stability $\left(\mathrm{cm}^{3} .100 \mathrm{~cm}^{-3}\right)$ & $0.5 \pm 0.02$ & $8.5 \pm 0.02$ \\
\hline
\end{tabular}

FWF - fine wheat flour, PP - pumpkin pomace.

Tab. 3. Physical properties of PP-incorporated crackers.

\begin{tabular}{lcccc}
\hline & $\begin{array}{c}\text { Volume } \\
\left(\mathbf{c m}^{3}\right)\end{array}$ & $\begin{array}{c}\text { Volume index } \\
(\mathbf{c m})\end{array}$ & $\begin{array}{c}\text { Width } \\
(\mathbf{T}, \mathbf{c m})\end{array}$ & $\begin{array}{c}\text { Thickness } \\
(\mathbf{W}, \mathbf{c m})\end{array}$ \\
\hline Control & $10.32 \pm 0.16$ & $2.93 \pm 0.05$ & $4.06 \pm 0.08$ & $0.95 \pm 0.03$ \\
PP 5 \% & $9.97 \pm 0.21^{*}$ & $2.74 \pm 0.03^{*}$ & $3.80 \pm 0.07^{*}$ & $1.03 \pm 0.03$ \\
PP 7.5 \% & $9.00 \pm 0.29^{*}$ & $2.47 \pm 0.11^{*}$ & $3.76 \pm 0.11^{*}$ & $1.10 \pm 0.05^{*}$ \\
\hline
\end{tabular}

*indicate a statistically significant differences $(\mathrm{p}=0.05), \mathrm{PP}-$ pumpkin pomace.

Tab. 4. Sensory evaluation of PP incorporated crackers.

\begin{tabular}{lcccccc}
\hline & Appearance & Odor & Taste & Hardness & Color & Overall acceptability \\
\hline Control & $8.11 \pm 0.03$ & $8.00 \pm 0.11$ & $8.11 \pm 0.10$ & $8.56 \pm 0.12$ & $8.67 \pm 0.08$ & $83.67 \pm 0.11$ \\
PP 5 \% & $8.22 \pm 0.10$ & $7.78 \pm 0.12$ & $7.44 \pm 0.09^{*}$ & $7.67 \pm 0.09^{*}$ & $8.33 \pm 0.06^{*}$ & $78.44 \pm 0.04^{*}$ \\
PP 7.5 \% & $8.43 \pm 0.12^{*}$ & $7.33 \pm 0.06^{*}$ & $6.33 \pm 0.11^{*}$ & $7.44 \pm 0.11^{*}$ & $8.10 \pm 0.11^{*}$ & $71.89 \pm 0.09^{*}$ \\
\hline
\end{tabular}

*indicate a statistically significant differences $(\mathrm{p}=0.05), \mathrm{PP}-$ pumpkin pomace. 
ratio values of crackers samples supplemented with PP. It can be explained that PP used in the cracker recipes affected spread ratio values due to its high water absorption capacity. Also, ingredients which absorb water during dough mixing and increase the dough viscosity may contribute to this effect (Turksoy and Ozkaya, 2011). The similar increase of thickness was also described by authors Khaliduzzaman et al. (2010) and Vasantharuba et al. (2012) for biscuits supplemented with various levels of potato flour. Similar results were obtained by Turksoy and Ozkaya (2011), who supplemented cookies with both pumpkin and carrot pomaces.

\section{Sensory properties of crackers}

The sensory evaluation is very important criterion in food industry. Sensory evaluation is usually performed towards the end of product development (Arshad et al., 2007).The crackers supplemented with different amounts of PP were evaluated for their sensory qualities and general acceptability. The results of sensory evaluations are presented in Table 4. The additions of PP to crackers negatively affected both odor and taste, and increased hardness of crackers. A similar effect was observed by Turksoy and Ozkaya (2011) for cookies enriched with pumpkin and carrot pomace. The authors indicated that hardness of crackers is caused by higher amounts of pumpkin pomace and their higher water holding capacity. Appearance and taste scores of crackers decreased by increased levels of PP in formulation as compared to control sample.

\section{Conclusion}

The objectives of this study were: determination of chemical and functional properties of PP, incorporation of $\mathrm{PP}$ to crackers, and the investigation of the impact of PP addition to quality and sensory attributes of final products. We found that PP has a relatively high content of TDF (51.77\%), high concentration of ash $(6.65 \%)$ and low content of fat (1.63\%). Moreover, it was found that PP displayed a relatively high hydration properties (WAC, SW) and OAC. Based on these facts, it could be suggested that PP can be used as a nutritional supplement for various cereal products. It was also shown that PP addition to crackers resulted in a significant reduction of volume, volume index and spread ratio of crackers. Sensory evaluation showed that higher amounts of PP negatively affected taste, odor, consistency and overall appearance of crackers.

\section{Acknowledgments}

This work was supported by grant VEGA No. 1/0487/16 and 1/0453/13.

\section{References}

Arshad MU, Anjum FM, Zahoor T (2007) Food Chem. 102: $123-128$.

Ayadi MA, Abdelmaksoud W, Ennouri M, Attia H (2009) Ind. Crops Prod. 30: 40-47.

Ayo JA, Ayo VA, Nkama I, Adewori R (2007) Niger. Food J. 25: 77-89.

Bouaziz MA, Amara HB, Attia H, Blecker Ch, Besbes S (2010) J Text Stud. 41: 511-531.

de Escalada Pla MF, Ponce NM, Stortz CA, LWT-Food Sci Technol. 40: 1176-1185.

Gajewski M, Radzanowska J, Danilcenko H, Jariene E, Cerniauskiene J (2008) Not. Bot. Horti Agrobot. ClujNapoca. 36: 73.

Grigelmo-Miguel N, Martín-Belloso O (1998) Food Res. Int. 31: 355-361.

Han J, Janz JAM, Gerlat M (2010) Food Res. Inter. 43: $627-633$

Jun HI, Lee CH, Song GS, Kim YS (2006) LWT-Food Sci. and Technol. 39: 554-561.

Kaur M, Singh N (2005) Food Chem. 104: 259-267.

Khaliduzzaman M, Shams-Ud-Din MN, Islam (2010) Bangladesh Agril. Univ. 8: 153-160.

Kohajdová Z, Karovičová J (2007) Zywn. Nauk. Technol. Ja, 4: 36-45.

Kohajdová Z, Karovičová J, Magala M (2011) Acta Chim. Slov. 4: 98-107.

Kohajdová Z, Karovičová J, Jurasová M (2012) Acta Sci. Pol., Technol. Aliment. 11: 381-387.

Kundu H, Grewal RB, Goyal A, Upadhyay N, Prakash S (2014) J Food Sci. Technol. 51: 2600-2607.

Nawirska A, Kwaśniewska M (2005) Food Chem. 91: 221-225.

Mora YN, Contreras JC, Aguilar CN, Meléndez P, De la Garza I, Rodríguez R (2013) Am. J. Food Nutr. 1: 27-33.

Muhamad II, Katan NSM, Shaharuddin S, Norulfairuz D, Zaidel AJ (2015) Adv. Res. Des. 4: 1-8.

Noor Aziah AA, Komathi CA (2009) Intern Food Res. 16: 479-482.

Pomeranz Y, Shogren MD, Finny KF, Bechtel DB (1977) Cereal Chem. 54: 25-41.

Perez P, Germani R (2000) Food Sci. Technol. 2: 186-192.

Raghavendra SN, Rastogi NK, Raghavarao KSMS, Tharanathan RN (2004) Food Res. Technol. 218: $563-567$.

Rodríguez R, Jimenez A, Fernández-Bolaños J, Guillén R, Heredia A (2006) Trends Food Sci. Technol. 17: $3-15$.

Siddiq M, Ravi R, Harte JB, Dolan KD (2010) LWT-Food Sci. Technol. 43: 232-237.

Sowbhagya HB, Suma FP, Mahadevamma S, Tharanathan RN (2007) Food Chem. 104: 1220-1225.

Sun-Waterhouse D, Teoh A, Massarotto C, Wibisono R, Wadhwa S (2010) Food Chem. 119: 1369-1379.

Turabi E, Summu G, Sahin S (2008) Food Hydrocoll. 22: 305-312.

Turksoy S, Özkaya B (2011) Food Sci. Technol. Res. 17:545-553.

Vasantharuba Seevaratnam PB, Premalatha MR, Sundaram SP, Arumugam T (2012) World J. Dairy Food Sci. 7: 79-84.

Wachirasiri P, Julakarangka S, Wanlapa S (2009) Songklanakarin J. Sci. Technol. 31: 605-611. 